\title{
Mountains and Stones in Prehistory of Humanity (Explanation of Wide Spread of Great Goddess Heart-Like Images Worldwide since the Stone Age)
}

\author{
Elena A. Mironova \\ Rostov State Economic University, Rostov-on-Don, Russia \\ Email: almir@donpac.ru
}

Received 26 September 2014; revised 22 October 2014; accepted 15 November 2014

Copyright (c) 2014 by author and Scientific Research Publishing Inc.

This work is licensed under the Creative Commons Attribution International License (CC BY). http://creativecommons.org/licenses/by/4.0/

\section{(c) (1) Open Access}

\section{Abstract}

This report is aimed to demonstrate unification of heart-like images of an anthropomorphic face (presumably, the reflection of Great Goddess), noticed by us, on the ancient petroglyphs, stones and mountains as well as on the artifacts of the Stone Age and later times across Eurasia, Africa, Oceania and America. This image/face of Great Goddess has stable and recognizable characteristic features, namely, a triangular cut in the center of a forehead and a triangular low part. This combination has been steadily repeated throughout the time and across different continents, thus proving the hypothesis about migration of the representatives of a unique and powerful ethnos which had an influencing religious cult and who spread the canonical representation of their main divinity on the material artifacts everywhere on their ways. In this article we present not only the early sources of that kind of image-on the mountains, megaliths and stones but also, put forward a statement about the possible initial place where from this image was spread.

\section{Keywords}

Great-Goddess Cult, Heart-Like Images, Carnac Megaliths, Petroglyphs, Polynesian Marae, The Shantarskie Islands, Oceania

\section{Introduction}

Methods which were used in this comparative research are visual analysis and comparative analysis. We compared and analyzed similar or look-alike images on the artifacts of the Stone Age and later epochs. Also we no- 
ticed that petroglyphs, megaliths and even small stones bore the image of Great Goddess who was the main figure in the Stone Age religion. This Goddess cult was investigated by James (1959), Gimbutas (1991), Golan (1991) and many other researchers who compared the small clay and stone anthropomorphic sculptures, depicting a woman in different postures-while sitting, standing between two animals, with very short hands (like a cross), squatted and many other.

In our previous works devoted to this matter, we also found another canonical way of depicting Great Goddess-as a face with typical signs: a triangular cut in the middle of a forehead and a triangular low part (Mironova \& Popov, 2013). This symbol was identified by us as an image of a female divinity in the Neolithic Epoch widely spread on the territories of Ural, Siberia, Altai and the Far East and which later was left on the Chalcolithic images in Europe (Greece, Cyprus), in Asia (Arabian Peninsula), and later was transferred to the Bronze Age (Figure 1).

Thus we can delineate the area of Great Goddess cult extension, and the proof for that-is the canonical images of her as a heart-like face with a triangular cut on the top-on all the continents: in Africa at the Dogons (Mironova, 2013), all around Eurasia, in Oceania and South America (Figure 2).

The spread of this symbol on the whole territory of Eurasia and further could be explained by migrations of the tribes, united by one and the same religious cult. The connection of this image with the religious cult is proved by the presence of altars, in particular, under the Vishera rock painting "Pisanyi kamen" (Figure 2(b)). Mask Mai in Papua New Guinea (Figure 2(c)) is used in the religious ceremonies even in our days (the Metropolitan Museum of Art). However, the similar anthropomorphic drawings are revealed also on the Japan islands and in Oceania South America. Surprisingly, they all repeat the major symbols of Great Goddess-the Deity of the Neolithic Age, testifying the deeply rooted unshakable traditions of the people of these regions.

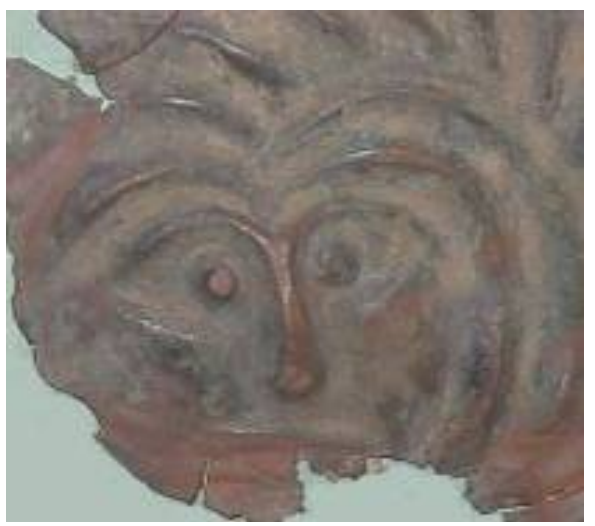

(a)

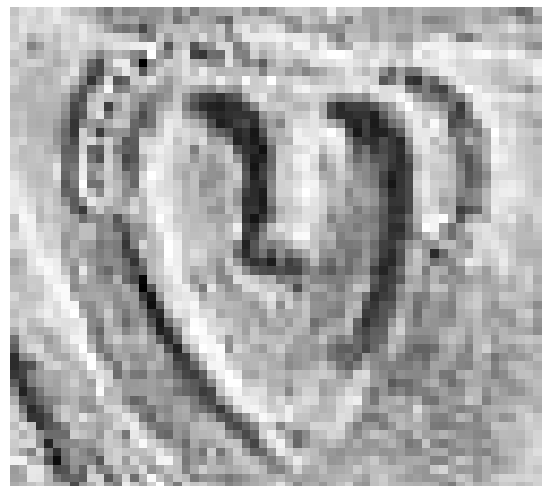

(d)

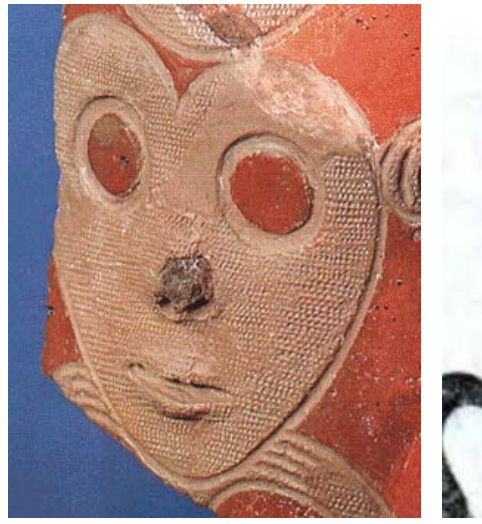

(b)

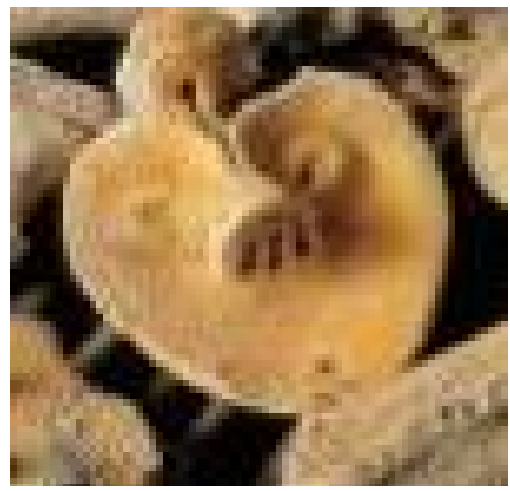

(e)

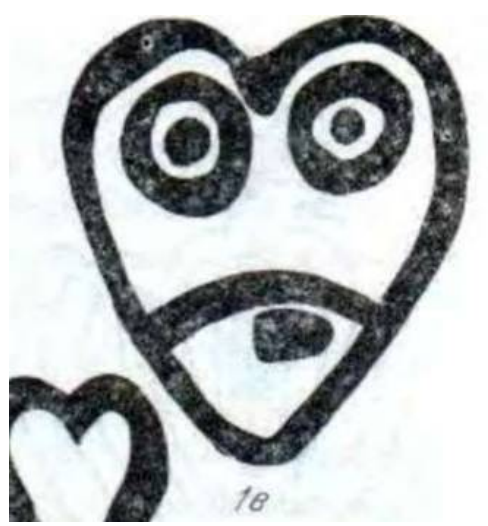

(c)

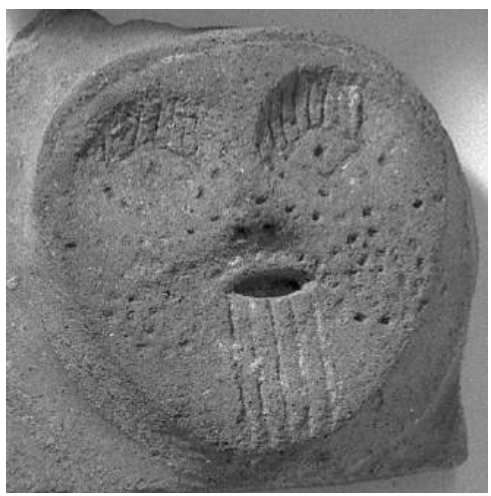

(f)

Figure 1. Magnified fragments of Great Goddess images: (a) artifact from excavations in Mezyn village (Ukraine) — heart-like image of Great Goddess (18 thousand B.C.); (b) ceramic fragment from Lower part of the Amur river (Russia); (c) petroglyph on the river Tom cliffs (Russia); (d) stone stele with carved anthropomorphic image, the shape of which resembles a heart, Troy (Turkey); (e) ceramic fragments (Dogu statuettes) discovered on the archaeological site Okumiomote, Asahimura, prefecture Niigata (Japan); (f) head, stone, the American Indians art. Brooklin Museum. 


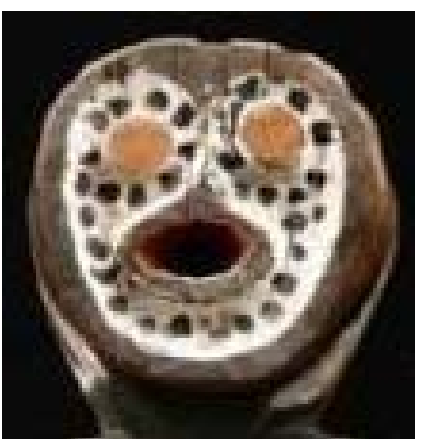

(a)

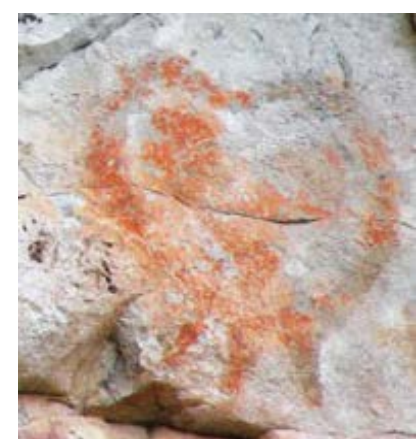

(b)

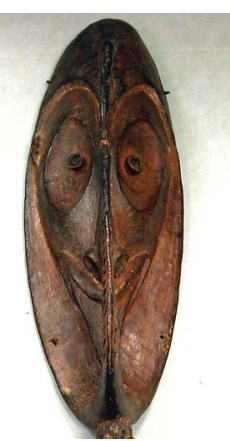

(c)

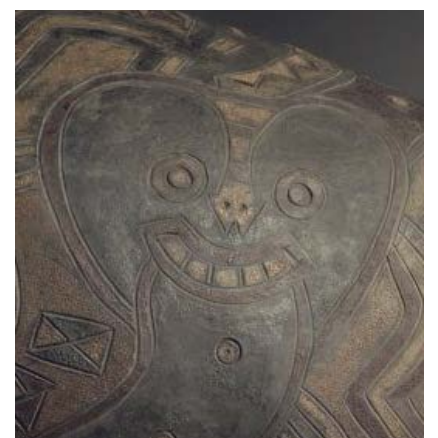

(d)

Figure 2. (a) Wooden Dogon's sculpture with a heart-like face (Mali, Africa); (b) Vishera rock painting "Pisanyi kamen" (Ural, Russia, Eurasia); (c) Mask Mai, XIX-XX century, Papua New Guinea, Latmul culture, wood carving, 53.3 см (Oceania); (d) Mythical figure on the large jar from the South coast of Peru, 200 B.C. (South America).

The problem of contacts between the tribes of the Far East, North America and the Pacific Ocean region peoples was discussed by many archaeologists. In science the paleocontacts of ancient tribes from Asia and America are considered to be proved, namely, the colonization of the American continent by the descendants from Asia via the Bering land bridge in the Ice Age when the level of the World Ocean was the lowest. Even more-the transition was not only via the "Bering bridge" but also "...via the general island chains-from Kamchatka and also via the Aleutian Islands... and not only by one wave or mass but by penetrating with small springs" (Okladnikov, 1973: p. 144).

\section{Heart-Like Images on the Stones}

Following this spread of divinity image not only on the ceramic and stone artifacts, but attentively observing also the megaliths in Carnac, Bretagne, we discovered the meaning of the long rows of standing stones: Ménec alignments, Kermario alignment and Kerlescan alignment-almost all of them bear the images of Great Goddess in the shape of a heart (Figures 3-7). This image sometimes is added by a sign " $\mathrm{M}$ " in the low part of a face (where mouth should be placed) in many cases.

As it was shown on Figures 4(b)-(c) the heart-like image "moves" from one side to another being lit correspondingly by the moving sun rays during the day. This effect was understood by the author of this article after comparing different sides of one stone in Carnac, and later-their photos, as it is presented on Figure 6.

On the majority of the Carnac stones these images could hardly be clearly seen now, as they are vague, though they could be distinguished. They exist almost on all the stones (Figure 3) and are accompanied by other signes and letters on the stone surface. The photograph of the stones (Figure 6) is done at the sunset and the rays of sun illuminate the stones from left side thus showing the irregularities of the stone in such a way that it is possible to see those faces-hearts as well as other signs-zigzags, swastics, S-hape ornaments and multiple letters M. The Carnac stones should be investigated under the different natural light-the sun rays: during the sunrise, the zenith and the sunset. Researchers will make many discoveries as soon as it became clear now-the function of the rows of megaliths is to be the sanctuary of Great Goddess and they bear her symbols for the protection of this territory and people inhabiting this territory.

There is also a presupposition that the signs of fertility and impregnation were carved on the stones-on their eastern side, i.e. on the side which "meets" the sunrise. These signs are: "Tausen", the sign $\mathrm{X}$ with bent upper ends and heart-like faces, probably personified productive, vital source of the whole nature. When the sun came to the horizone and lit the western side of the Carnac stones, the letters $M$ and other symbols of the second hypostasis of Great Goddess, namely, to be the protector of sleeping/passing away world, became clear.

Surprisingly enough, but the look-alike images on the stones are seen on the opposite coast of Eurasia-on the sea-coast in China (Figure 8).

Image like the one on the previous photo is found in Taiwan (Figure 9).

The heart-like images, engraved on the stones, are widely spread in Altay, in Baikal region and in Primorye. Two of these are presented on the Figures 10(a)-(b).

As it will be shown further, this kind of Great Goddess images are copied on the islands of Polynesia. Now 


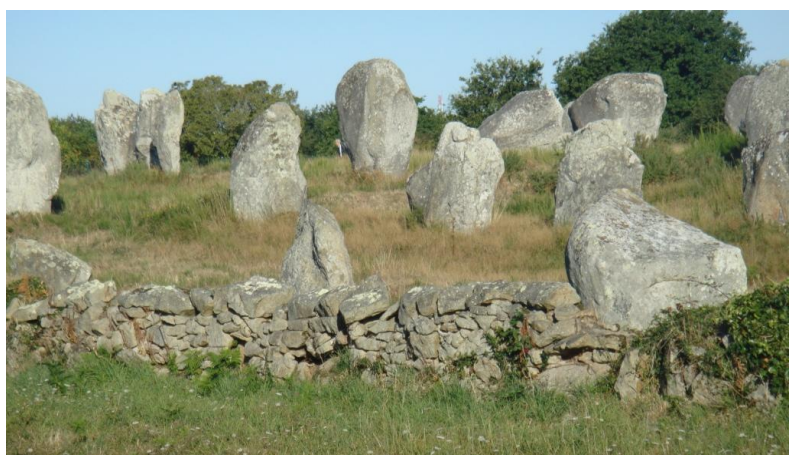

(a)

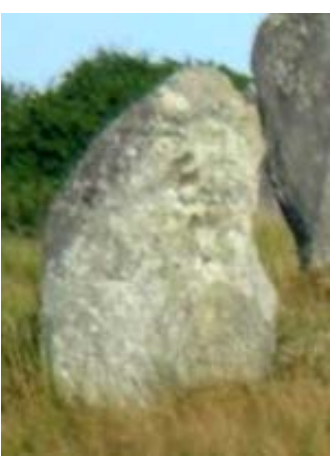

(b)

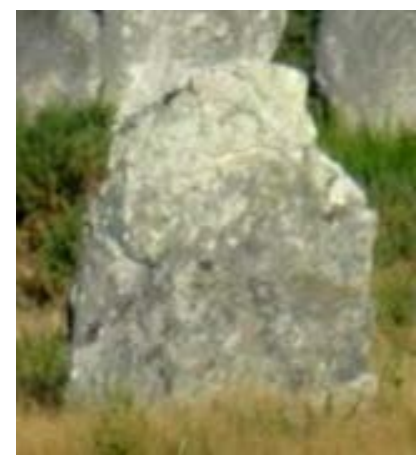

(c)

Figure 3. (a) Stones of Carnac (Bretagne, France) with heart-like images, signs as the letters S and M. This photograph is made at the dawn and the images are exposed to the sun (Photo by Elena A. Mironova); (b) Magnified image of the stone from the left side of the previous photo, with indistinctly seen heart-like face; (c) Magnified image of the stone from the right side of the previous photo, with more clearly seen heart-like face.

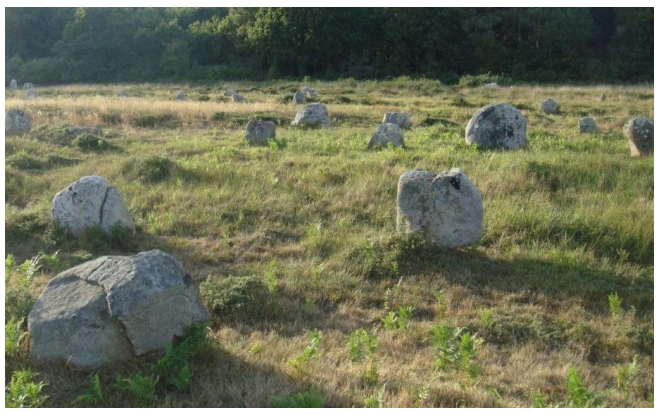

(a)

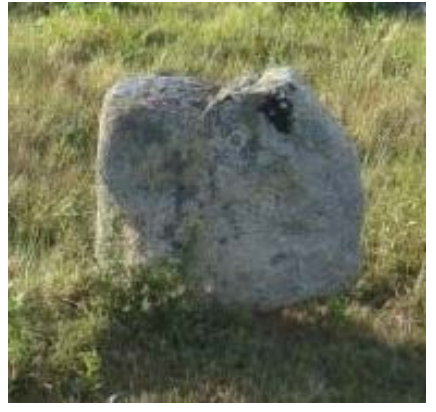

(b)

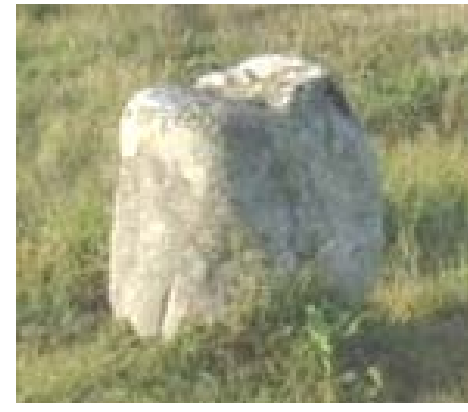

(c)

Figure 4. (a) Sunset in Carnac, Bretagne. The rows of megaliths lit from the west with southern part of all the stones in the shadow (Photo by Elena A. Mironova); (b) Magnified image of a stone with heart-like face (we can identify the triangular cut in the center of upper part, two eyes and vertical nose); (c) The same stone from another angle-the corner of this stone has also two upper arcs and recognizable small eye to the left, which is slightly lower than the eye to the right, belonging to the previous image and being the eye to the left on it (meanwhile more detailed analysis of the stone surface is needed on the site as soon as due to erosion the carved lines are now indistinct).

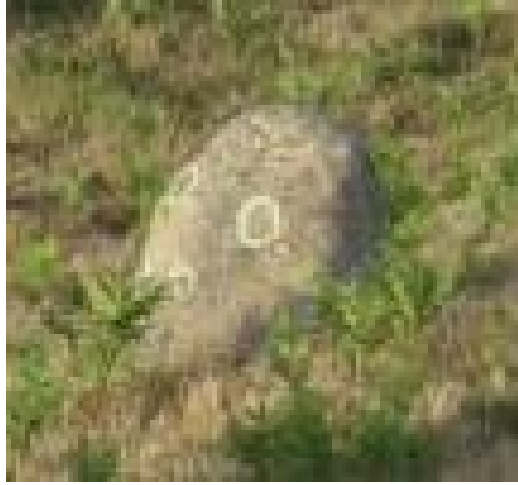

(a)

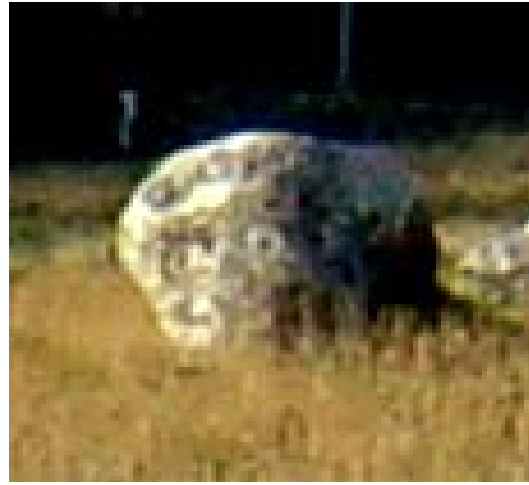

(b)

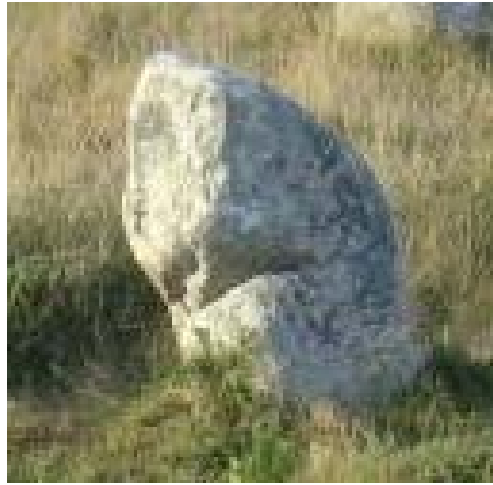

(c)

Figure 5. (a) Stone with "face"- one of many among Carnac stones; (b) Distinctively seen eyes on the surface of a stone from Carnac; (c) A stone nearby the previous stones with carved upper arcs and a carved horizontal "mouth" below (the stone doesn’t stand fully vertical due to time influence) (Photo by Elena A. Mironova).

we point out a very interesting peculiarity — the size of suchlike images varied from the tiny ones, made up of the pebbles, till the incredibly large — of a mountain size. Thus V.A. Gorodtsov writes about stone instruments 


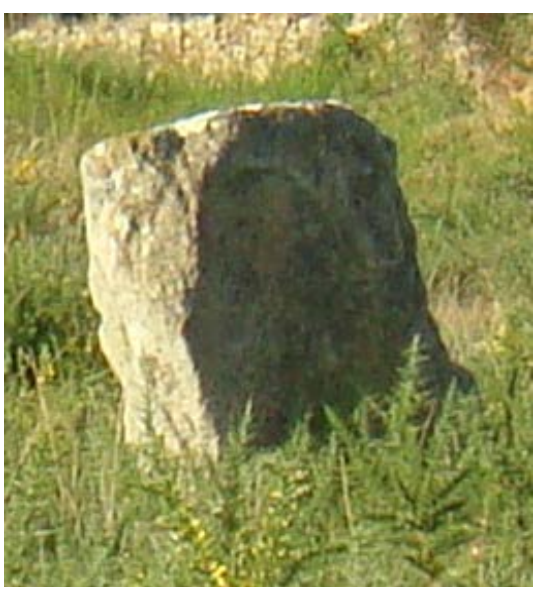

(a)

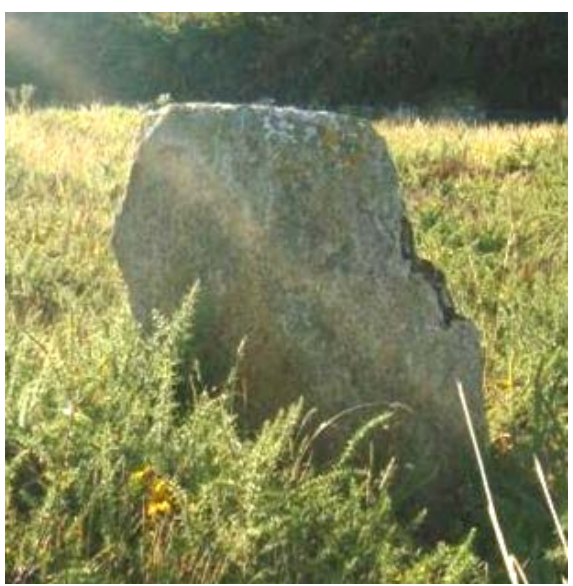

(b)

Figure 6. The effect of the "heart-like" face- " "gliding" through/on the surface of the stone. Each image (a)-(b) is engraved on two of the stone sides-southern side and western side. Wherever the sun lits a stone surface, we get an image of Great Goddess (Photo by Elena A. Mironova).

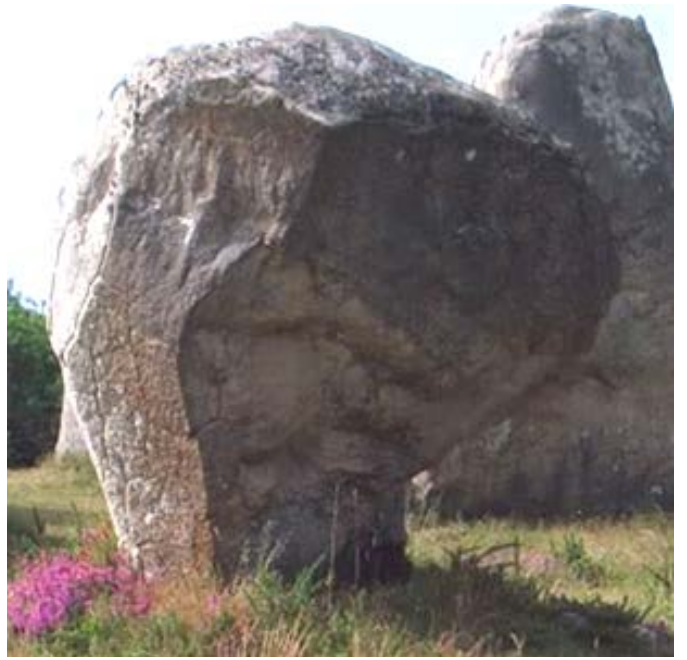

(a)

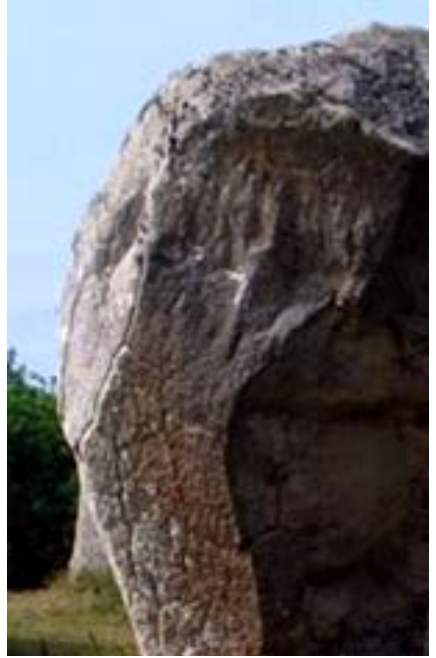

(b)

Figure 7. The same effect of "gliding" image of Great Goddess (a)-(b) - the "heart-like" faces carved on two sides of a stone, clearly seen on this stone.

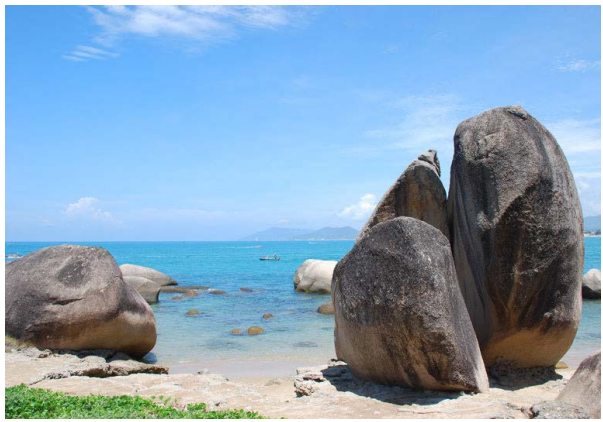

(a)

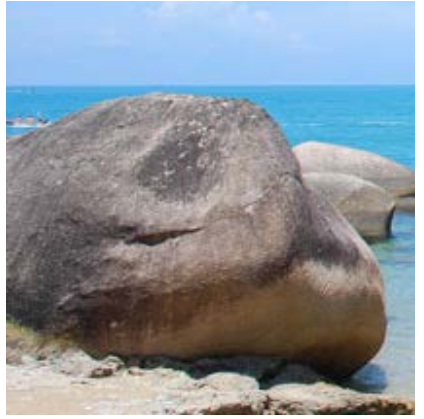

(b)

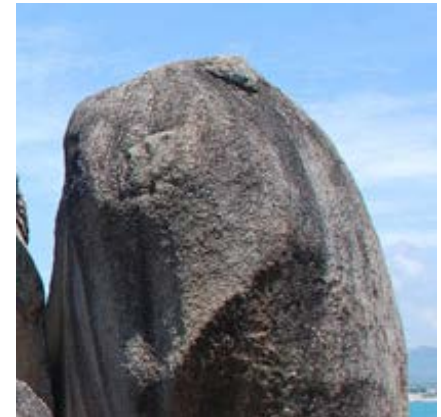

(c)

Figure 8. (a) The group of stones on China sea-coast with the anthropomorphic images; (b) The left stone with "face" (magnified); (c) The highest right stone with a "face" (magnified). 


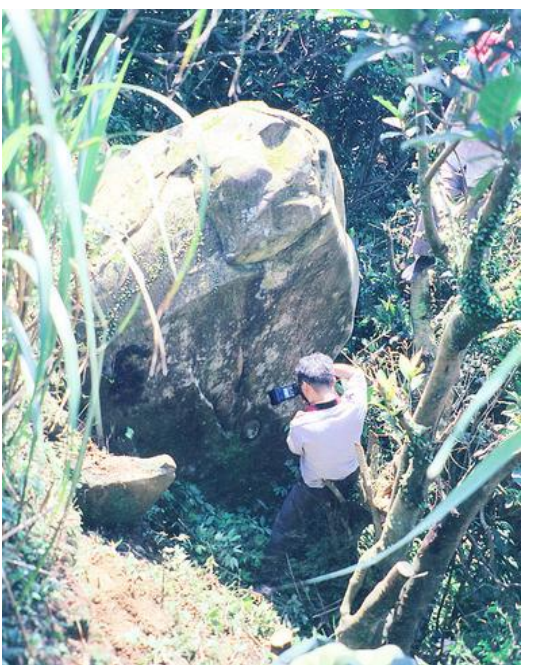

(a)

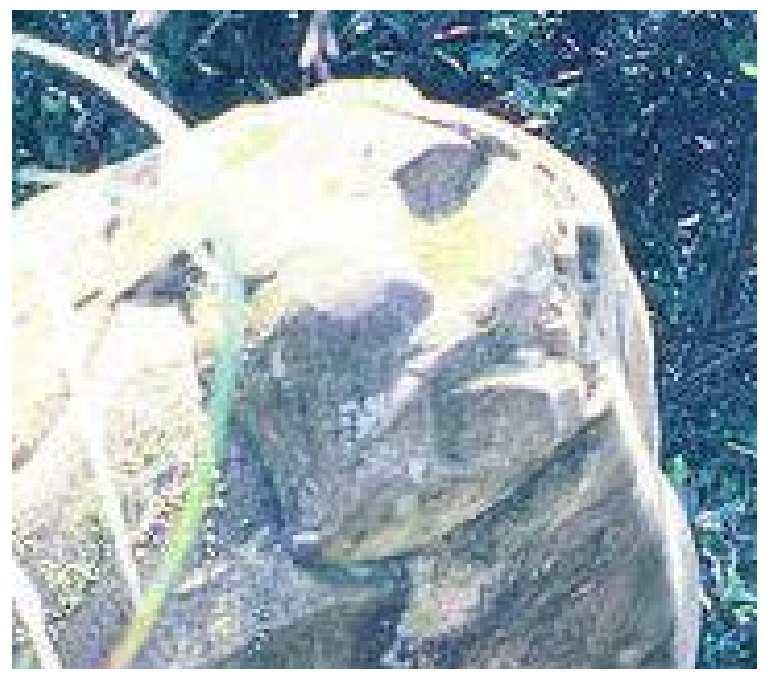

(b)

Figure 9. (a) Anthropomorphic image on the stone as a face-heart, island Taiwan; (b) Magnified fragment of the stone with "face".

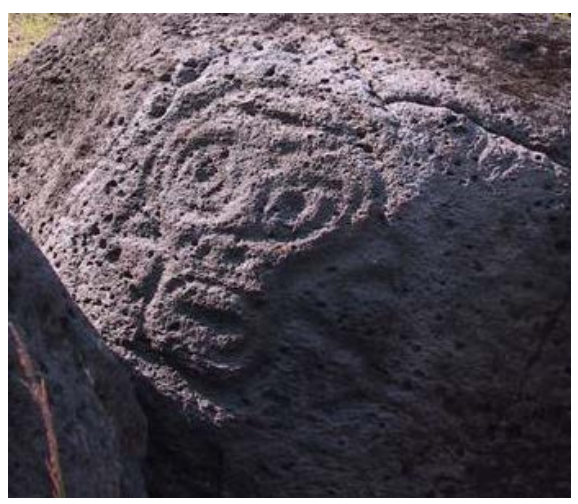

(a)

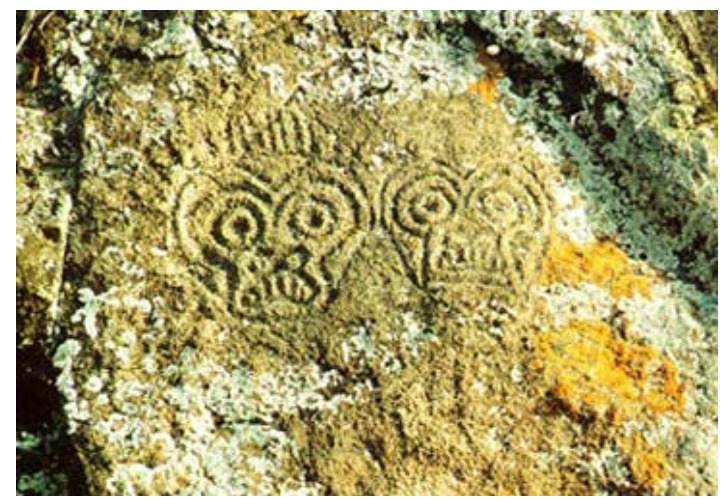

(b)

Figure 10. (a) Petroglyph of Sikachi-Alyan as a heart-like face (the Far East, Russia); (b) Petroglyphs from the Far East- the same heart-like faces (Russia).

from the Urtuiskaya settlement (south-eastern Zabaikalie, the Urtui river, basin of the Amur: "A group of scraper-like small objects of enigmatic usage is very interesting. There are seven of them in the collection: sixfrom chalcedony and one-from greenish-yellow jasper. Till now this kind of objects were referred to the microlithic scrapers, however, it is difficult to agree with this because these objects are too small: with a hand but without a handle, it is hard to work with them. Meanwhile, they are difficult to be connected with the handles as soon as they are thick and at the same time are tiny. The biggest of them is the object made of jasper, with the sizes: $1.7 \mathrm{sm}$ length and $1.5 \mathrm{sm}$ width, but its blade is manufactured intricately and the whole object reminds heart or a spot of an ace of hearts with cut top. All these facts stand for more decorative rather than for utilitarian purpose $\langle\ldots>$ Curiously enough, but the same microliths were found in other places, for example, in Kalmyk steppes of Primorskoye region. The Kalmykian scrapers-like objects, as well as the Urtuiskie objects are supplied with the microlithic types of stone instruments. The similar cases are known in other places (in Crimea)" (Gorodtsov, 1936: pp. 105-113).

The petroglyphs identical to the ones, shown on the Figure 10, are found on the stones from Bella Coola valley (Canada) (Figure 11(a)) and on the Virgin Islands (Figure 11(b)-(c)).

\section{The Heart-Like Images on the Mountains}

One of the modern scientific areas of focus is hierotopy (from Greek "ieros”- “sacred” and "topos”- “place”) 


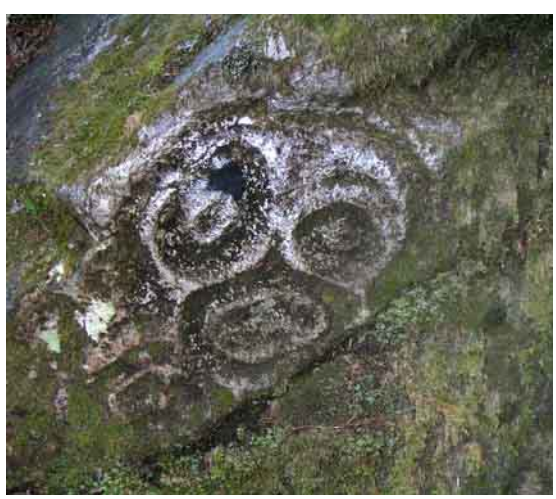

(a)

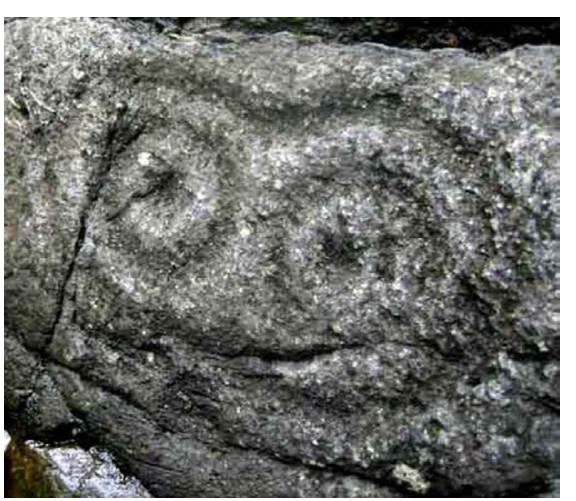

(b)

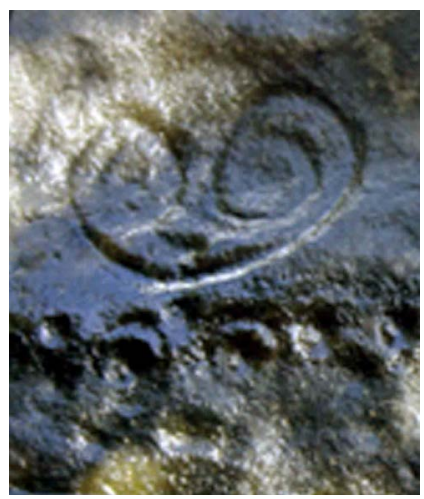

(c)

Figure 11. (a) Bella coola valley (pre Haida) Tiki (British Columbia, Canada); (b)-(c) two Taino petroglyphs from the island Saint John (The Virgin Islands).

which is oriented to study sacred areas as a kind of human creativity. Hierotopic approach was formulated by A. M. Lidov (Lidov, 2006).

The term "sacred area” generally correlates with religion. The Abkhazian scientist R. M. Bartsyts, speaking about religious syncretism of Abkhazians, investigated cult complexes around Gagra, in the watershed of the Bzyb-Gudauta region, Abkhazia, Caucasus (Bartsyts, 2013).

A sacral area in Abkhazian and Adyghe cultures is closely connected with the traditions. People gather there in our days to pray, to commit oaths, to celebrate good harvest etc. Very often it is a definite geographical object (a mountain, a promontory, a settlement) or a natural object (a forest, a wood, a tree, a spring) (Sokolova, 2013).

Obviously, the more impressive is the geographic/natural object, the more powerful it is in the eyes of people living nearby. If we observe the most significant of all natural objects-the mountains, we will discover that since ancient times almost all of them were this kind of sacred areas.

The origin of "heart-like face"-the canonical Great Goddess image-will be shown in this research for the first time. We managed to find the possible source of all similar images. We consider, that the prototype of this stable religious symbol was Chomolungma mountain (Everest), which is called on Nepalese Sagarmatha"mother of the mountains" (Figure 12).

It is remarkable, but in the Pyrenees there is a village in $80 \mathrm{~km}$ from Pamplona (Spain), which is called Sugaramurdi (Spanish: Zugarramurdi). This is the region of compact basks living. Sagarmatha-Sugaramurdi-the definite similarity can be traced in this pair of place-names.

If we can cast a look at the low pick of Chomolungma, as it is presented on the Figure 12, we will notice that it reminds us a heart-like face, which we considered earlier in this paper and which is met also on the Altay petroglyphs (Figure 14(a)). In Caucasus, near the mountain Elborus, there are two mountains: Donguz-Orun and Nakra Tau (Figure 13).

What draws attention most-is the "mirror" formation of rocky folds on these mountains-on the low pick of Chomolungma and on Nakra Tau with the only one difference: the image on Chomolungma is convex and the image on Nakra Tau is concave (Figures 14(b)-(c)).

Another example of a heart-like image on the cliffs is presented on the Shantarskie Islands (Far East, Russia). It's a wild place with no people, only bears and other animals inhabit this territory. There are also a lot of fish and birds. The landscapes strike rare travelers with their beauty: there are plenty of cliffs, dozens of waterfalls, unique rivers and lakes. The heart-like image was discovered by us on one of the pictures from the Shantarskie Islands (Figure 15).

The same heart-like image is clearly seen on the sea-front ascending slope of the mountain and the triangular cut is seen on the top of this image. If it is an element of a natural change in the structure of a cliff, than why this image bears two eyes on their proper places? They are also visible on this photo.

Another region that drawn our attention in this context is Oceania (Micronesia, Melanesia and Polynesia). We found the same image on the island Bora-Bora, French Polynesia (Figures 16(a)-(b)).

Nearby Mountains Otemanu and Pahia there are more than 40 ruins of Marae-the ancient cult sites. These mountains are of volcanic origin. According to ancient believes the stones of Marae were associated with the 


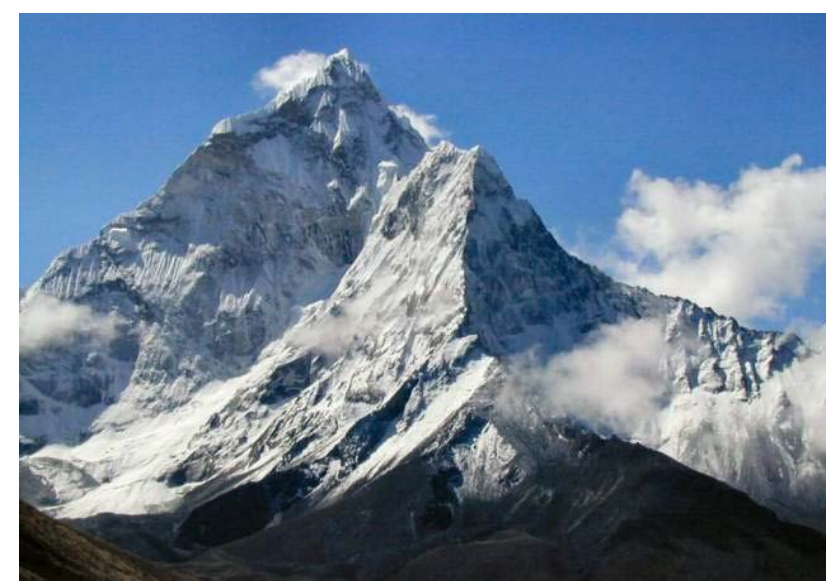

Figure 12. Chomolungma. Second top (lower) has a cut in the center.

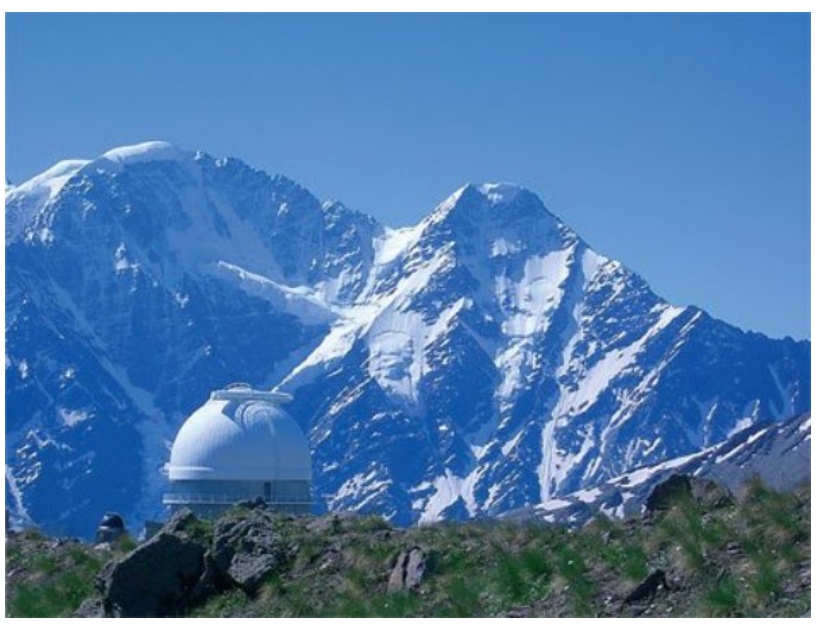

Figure 13. Mountains Donguz-Orun and Nakra Tau (which has a cut in the middle of the top). These mountains are not far from Elbrus (Caucasus, Russia).

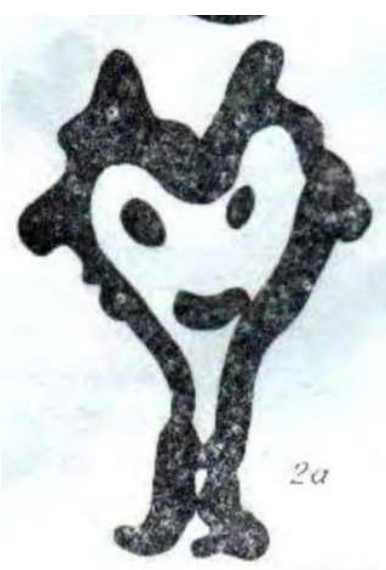

(a)

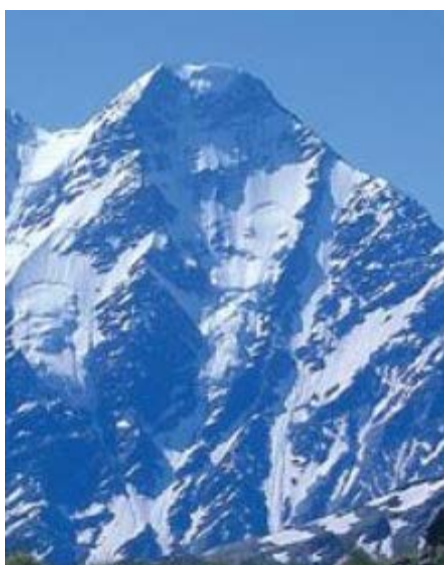

(b)

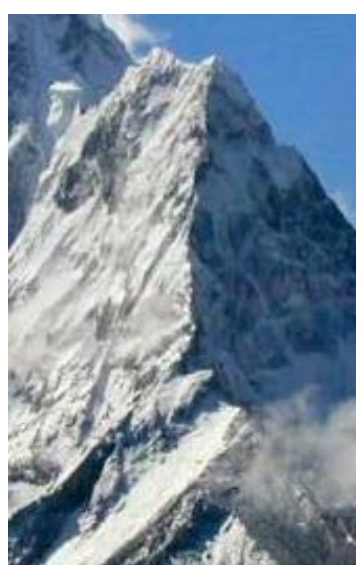

(c)

Figure 14. (a) Petroglyph from the rocks on the river Tom (Siberia, Russia); (b) Magnified image of Nacra-Tau with a cut in the centre (Caucasus, Russia); (c) Magnified image of one of the Chomolungma picks with a cut in the centre. 


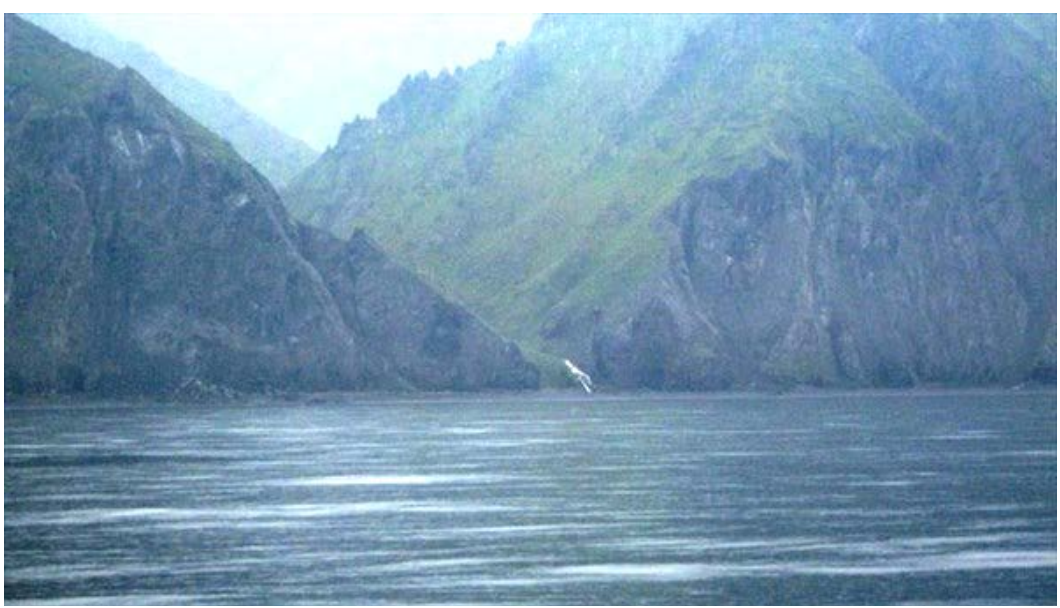

(a)

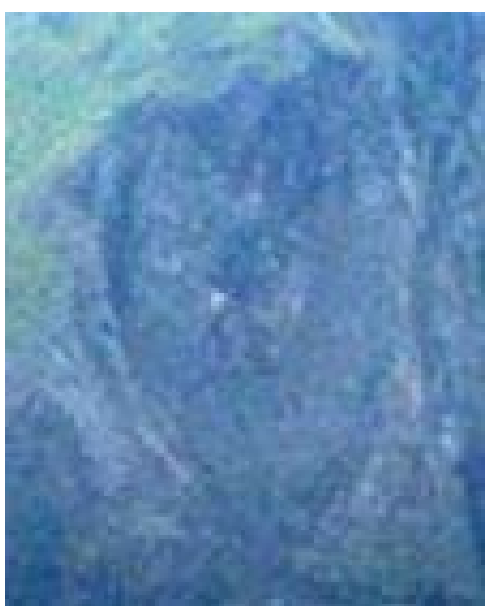

(b)

Figure 15. (a) The Shantarskie Islands in the Sea of Okhotsk. Alexander bay (the Far East, Russian Federation); (b) Magnified fragment of a rock with hear-like face.

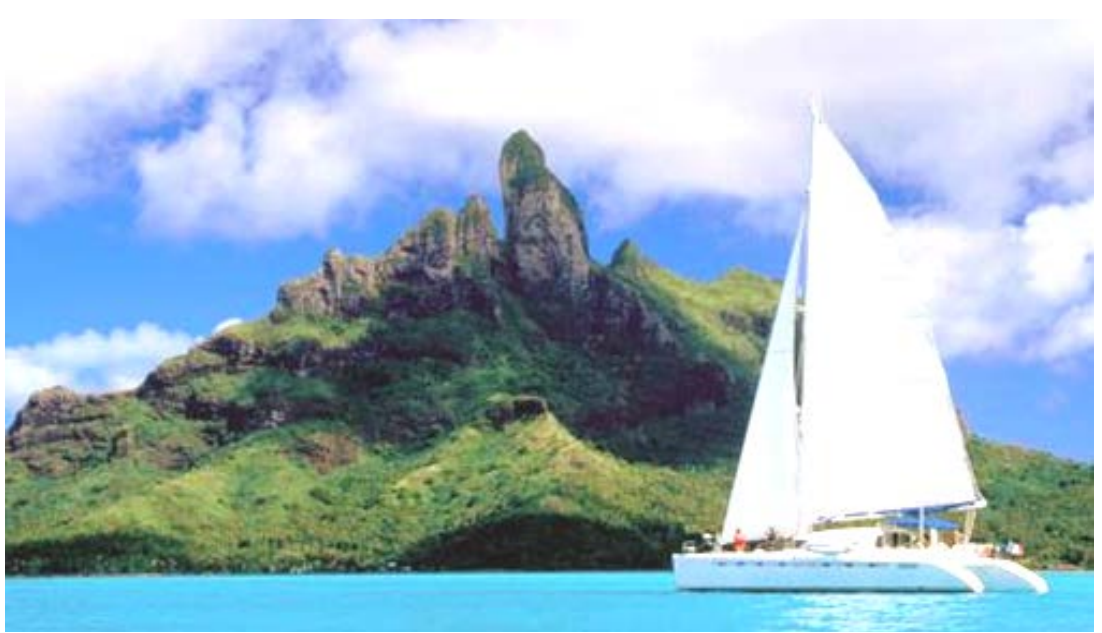

(a)

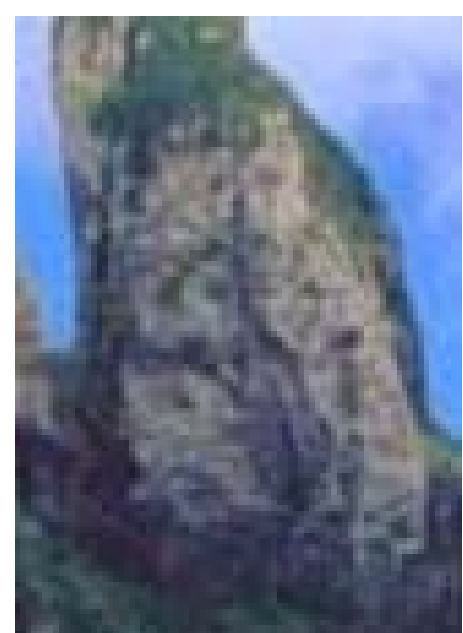

(b)

Figure 16. (a) Mountains Otemanu (727 m) and Pahia (661 m). Mountain Pahia has an antropomorphic heart-like image on its sea-front surface (Bora-Bora Island, French Polynesia); (b) The magnified fragment of mount Pahia with antropomorphic image.

mountain Otemanu. There are 42 kinds of ancient civilization traces on the island including "marae” Vaiotaha on the north of Poovai bay, Farerua or Marotetini-the biggest ritual stone on the island and also one of the most beautiful "marae" in Polynesia-Taianapa. Figure 17 demonstrates Marae Marotetini with the stones which bear the images similar to the ones described in this article. It is possible to recognize them, because the definite pattern is observed: stone on the magnified pictures Figures 18(a)-(b) has a so-called "gliding effect", as if face glides through the surface of this stone, every time one eye on this face plays the function of both-right and consequently-left eye depending on whatever facet of a stone is lit by the sun (the same principle as in Carnac, Bretagne).

The carving technic of ancient people was so perfect that allowed them to deal not only with the small pebbles by carving and incising them to create inscriptions and images (Mironova, 2012), but also with the big rocks and even mountains. As an example we bring the first Buddist temple in China which was created in the region of picturesque mountain Amaishan (the territory of modern province Sychuan) in $1^{\text {st }}$ century AD. The most significant here is the statue "Big Buddah" in Lashan (30 km away from Amaishan) which is cut out of the whole rock in YIII century AD. Its height is $71 \mathrm{~m}$ and it is considered to be the biggest sculpture of Buddha in the world (Figure 19). 


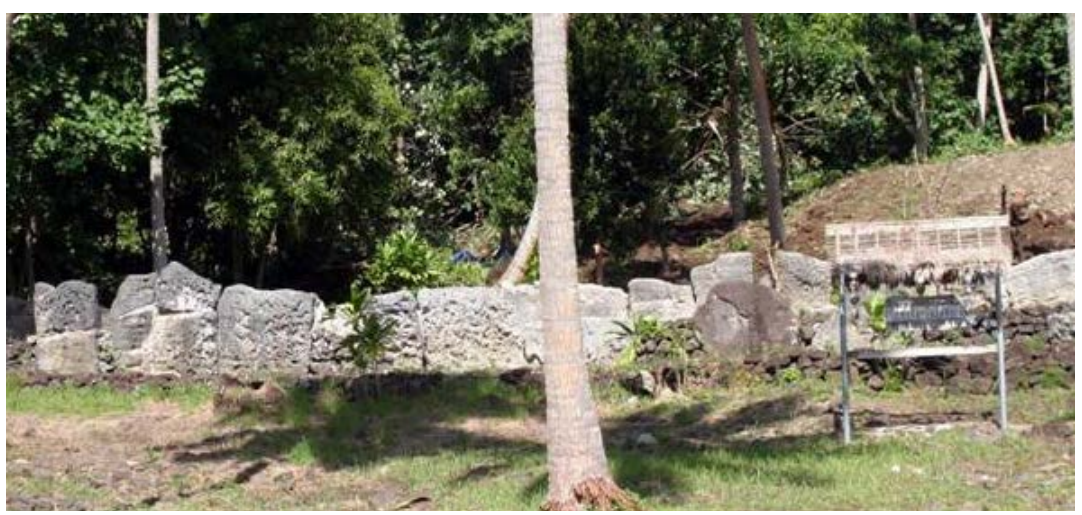

Figure 17. Stones from Marae Marotetini, Bora-Bora Island (French Polynesia).

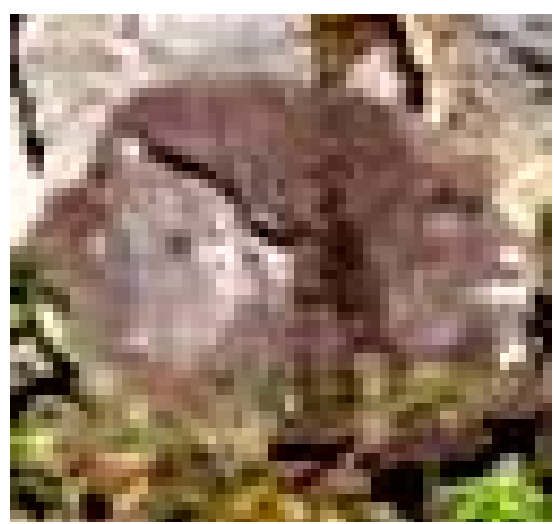

(a)

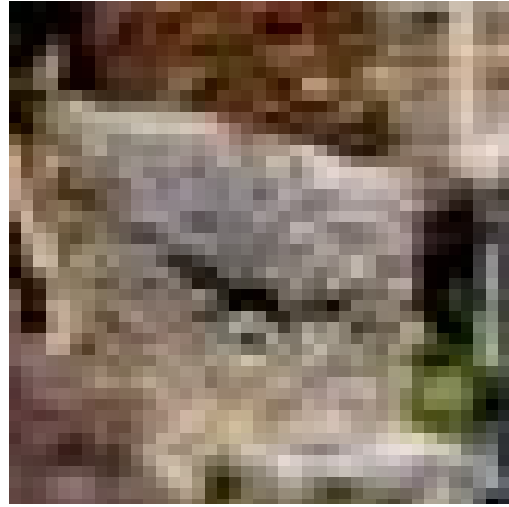

(b)

Figure 18. (a)-(b) Magnified images of the stones which bear the anthropomorphic carvings. Marae Marotetini, Bora-Bora Island (French Polynesia).

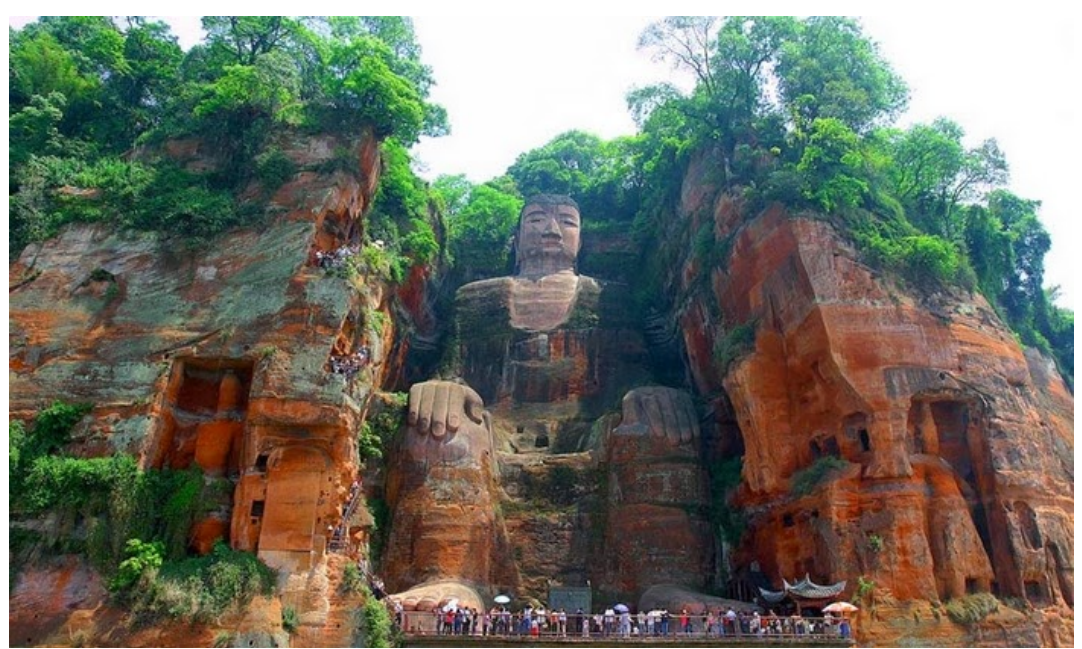

Figure 19. Statue of Buddah Maitreiya in Leshan (China).

Obviously, the practice of carving the bas-relifs on the mountain surfaces is not unique. It is spread all around the ancient world - the Egyptian images of Pharaoh Ramses in Assuan, Jordanian town Petra with El Hazne cut in the mountains, the Lycian graves in Turkish Dalyan and other. That is why it isn't worth admiring that cutting and polishing a mountain surface till necessary format was possible in the past (for fortification or occult reasons). But to trace this tradition emerging dozens thousand years ago — this is a real enigma. 
Bright illustration of this statement is another "face" on the mountain surface: on Waya Island, Fiji archipelago, in the bay called Liku-Liku (Figure 20).

The Hawaii Islands can present even greater surprise. We can observe there not only the image on the vertical surface of Nuuanu Pali Lookout (Figure 21(a)), but also the identical petroglyph on the stone (Figure 21(b)).

Among many archeological attractions at Hawaii Volcanoes National Park are the ancient images near the southern flank of Kilauea volcano known as the Pu'u Loa Petroglyphs. These include thousands of drawings etched into the hardened lava, some showing human representations known as anthropomorphs.

The Pu'u Loa Petroglyph Field was first observed by Reverend William Ellis, a missionary to the Hawaiian and Society Islands. He recorded seeing the petroglyphs at Pu'u Loa in 1823, describing them as "straight lines, semicircles, or concentric rings, with some rude imitations of the human figure, cut or carved in the compact rocks of lava."

Ellis believed the etchings were left by visitors to the area. A number of concentric circles with a dot or mark in the center indicated the party who had circumambulated the island. In 1914, however, anthropologist Martha Beckwith visited Pu'u Loa and interpreted these markings as family symbols. She said that they show how many members there were in a family and what their ranks were in the tribe. Today, experts still debate the meaning.

\section{Another Image of Greate Goddess and Swastica as one of the Arians Symbols}

Together with the heart-like image of the Great Goddess on the Polynesian Islands we can also notice the squatted image of a woman on the front one of a so-called Mens' Meeting House. The meaning of some of the pictures is now forgotten. On the contrary, the custom to transfer the images from the old houses to the new ones is still alive. This is a way to transfer knowledge about some events http://lib7.com/okeaniya/89-palay-mikronezija.html). One of suchlike images is-swastika (Figure 22). As it was shown in the work (Klyosov \& Mironova, 2013) swastika has accompanied the Aryans in the course of their migrations.

\section{Conclusion}

In conclusion, we can say that the "heart-like image", presented on the artifacts since the Stone Age, had deep religious roots. It is spread across Eurasia and could be met in Africa, Polynesia and America. It depicts the Great Goddess of the Stone Age and could be found on the objects of different size-on the pebbles, on the

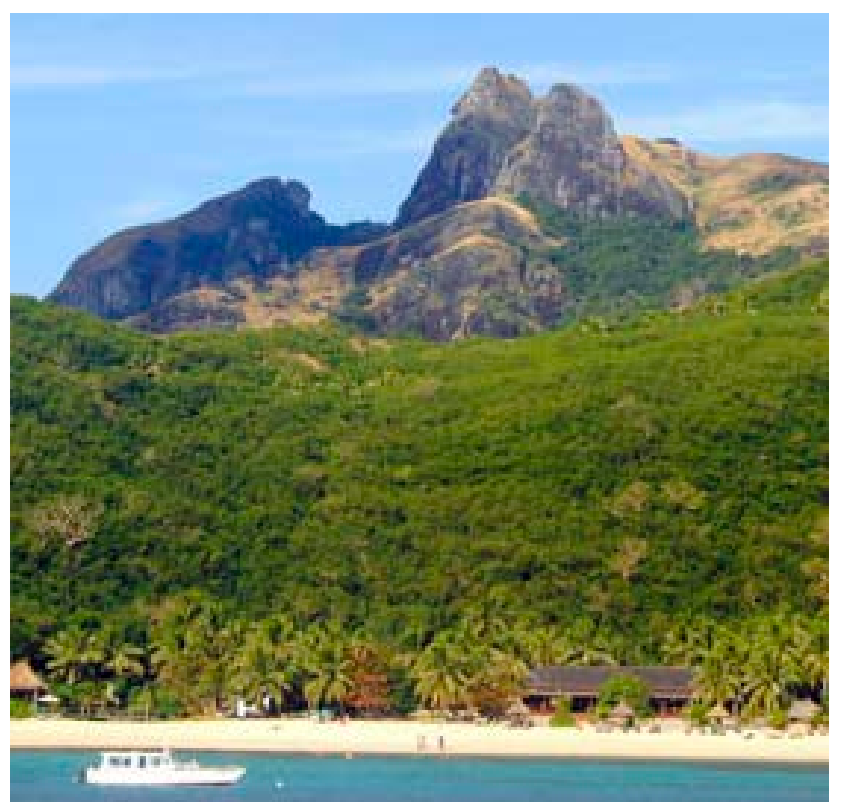

(a)

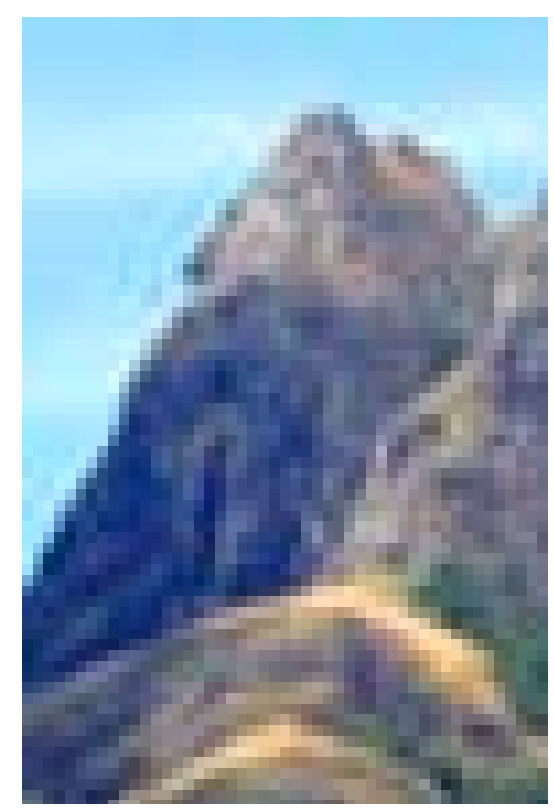

(b)

Figure 20. (a) LikuLiku Bay, Waya Island, Fiji-Nulauwaku village (Polynesia); (b) Magnified fragment of the rock in LikuLiku Bay with recognizable anthropomorphic image. 


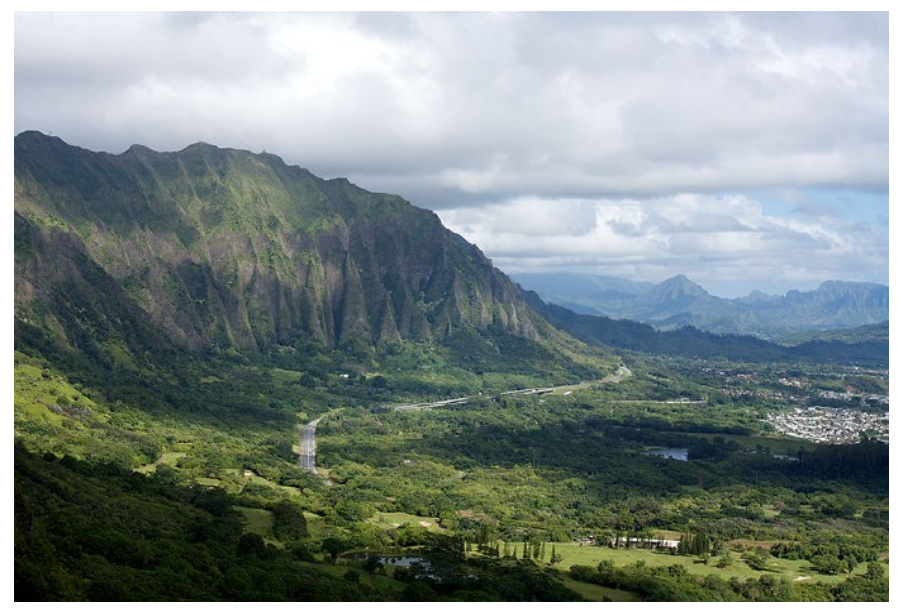

(a)

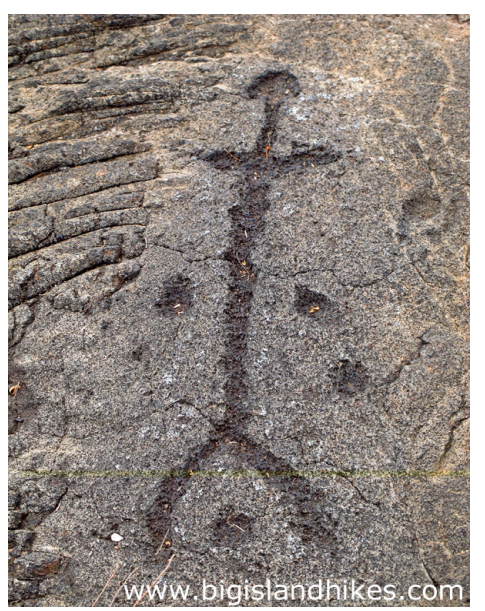

(b)

Figure 21. (a) 1000 feet above Oahu's coastline is Nuuanu Pali lookout (the Hawaii islands); (b) petroglyph from Hawaii Volcanoes National Park (the Hawaii islands).

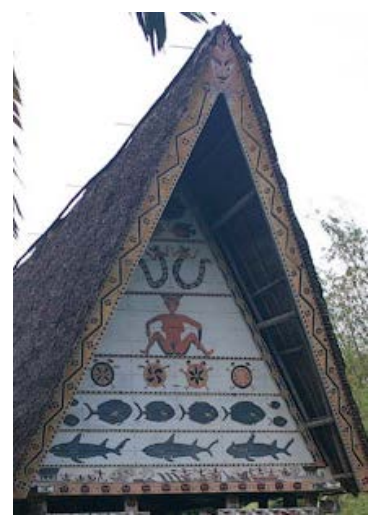

(a)

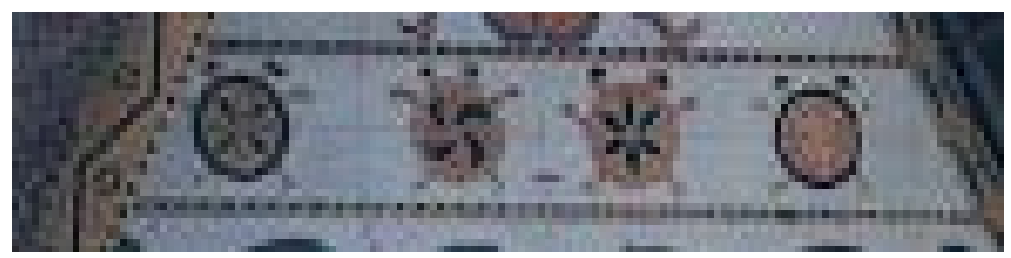

(b)

Figure 22. (a) Men’s Meeting House at Belau National Museum Koror, Republic of Palau (Oceania, Micronesia); (b) one of the symbols from Men’s Meeting House—swastika (magnified) (photo by Nico Tondini).

stones and even — on the mountains. We put forward the idea that Chomolungma was the initial place where the image of Great Goddess was "seen” by the ancient people. Further this natural image was copied on the petroglyphs, clay artifacts and was carved on the stones.

We discovered the function of the Carnac rows of stones in Bretagne (France) — as being the visual representation of Great Goddess, as soon as they bear the heart-like face on every side and even angle (the "gliding” effect). Almost all of them bear the "portraits” of Great Goddess, thus performing the function of its sanctuary, the religious place or sacred area (in the terms of new approach in science-hierotopy). Further research of every stone in Carnac, Bretagne (France) under the different angle of the sun rays, for enriching the statistic database, is necessary to restore the details of the whole cult of Great Goddess.

\section{References}

Bartsyts, R. M. (2013). Sanctuaries of Abkhazia in Modern Ceremonial Practice. Proceedings of Adyghe State University, 3. http://cyberleninka.ru/article/n/svyatilischa-abhazii-v-sovremennoy-obryadovoy-praktike-rabota-vypolnena-pri-podderzhk e-rgnf-proekt-13-26-12002-svyatye-mesta-abhazov-i

Gimbutas, M. (1991). The Civilization of the Goddess: The World of Old Europe (p. 529). San-Francisco, CA: Harper.

Golan, A. (1991). Myth and Symbol. South Deerfield, MA: Schoen Books.

Gorodtsov, V. A. (1936). Urtuiskaya Microlithic Settlement in the Watershed of the Amur. Soviet Archaeology, No. 1, 105113. 
James, E. O. (1959). The Cult of the Mother Goddess: An Archaeological and Documentary Study. New York: Frederick A. Praege.

Klyosov, A. A., \& Mironova, E. A. (2013). A DNA Genealogy Solution to the Puzzle of Ancient Look-Alike Ceramics across the World. Advances in Anthropology. 3, 164-172. http://dx.doi.org/10.4236/aa.2013.33022

Lidov, A. M. (2006). Hierotopy. Study of the Sacral Places as a Kind of Creativity and as a Subject of Historical Research. Hierotopy. Vol. 1, Creation of Sacral Places in Byzantium and ancient Russia, M, Indric., 9-31.

Mironova, E. A. (2012). Engraved Pebble from Petra-tou-Romiou (Cyprus). Academy of Trinitarizm, M., No. 77-6567, Publication 17598. http://www.trinitas.ru/rus/doc/0211/005a/02111154.htm

Mironova, E. A., \& Popov, V. V. (2013). Evidence of Unified Religious Cult Spread in the Neolithic Age on the Territory of Eurasia, Japan and America (Heart-Like Images of the Face of the Great Goddess). Proceedings of the Academy of DNA Genealogy, 6, 1103-1113. http://aklyosov.home.comcast.net/ aklyosov/06_06_2013.pdf

Mironova, E. A. (2013). To the Issue of the Similar Ornaments on the Objects of Cult, art and Every-Day Life of the Dogons and Also on the Most Ancient Artifacts of Eurasia, Japan and America. Proceedings of the Academy of DNA Genealogy, 6, 1697-1723. http://aklyosov.home.comcast.net/ aklyosov/6_10_2013.pdf

Okladnikov, А. П. (1973). Asia-America: Ancient Bridge. Sibirskie ogni, 11, 136-145.

Sokolova, A. N. (2013). Sacred Places of the Abkhazians and Adyghes as an Object of Scientific Research. Proceedings of Adyghe State University, 3. http://cyberleninka.ru/article/n/svyaschennye-mesta-abhazov-i-adygov-kak-obekt-nauchnogo-issledovaniya-2

The Metropolitan Museum of Art. The Collection Online. Mask Mai. http://www.metmuseum.org/collection/the-collection-online/search/316367

Pu’u Loa Petroglyphs. http://www.city-data.com/articles/Puu-Loa-Petroglyphs-Hawaii-Volcanoes.html 


\section{Appendix}

The following reference data have been selected for "heart-like faces" images

Figure 1(a): http://www.videnovum.com/ukraine/mezin-155/arhaeological-museum-140

Figure 1(b): http://www.trinitas.ru/rus/doc/0211/009a/02111008.htm

Figure 1(c): http://www.altaj.ru/petroglify-urala?page $=0 \% 2 \mathrm{C6}$

Figure 1(d): http://lib3.podelise.ru/docs/137/index-31085.html?page=2

Figure 1(e):

https://heritageofjapan.wordpress.com/just-what-was-so-amazing-about-jomon-japan/ways-of-the-jomon-world2/jomon-crafts-and-what-they-were-for/the-mystery-of-the-clay-dolls/

Figure 1(f): http://www.brooklynmuseum.org/opencollection/objects/45310/Head\#

Figure 2(a): http://www.artvalue.com/auctionresult--dogon-culture-mali-statue-2621862.htm

Figure 2(b): http://lenkovsky.livejournal.com/28477.html

Figure 2(c): $h$ ttp://www.metmuseum.org/collections/search-the-collections/316367

Figure 2(d): $\underline{\text { http://www.brooklynmuseum.org/opencollection/objects/76232/Large_Jar }}$

Figure 7: https://www.flickr.com/photos/levalet/6992294679/in/photostream/

Figure 8: http://breez-tour.ru/11

Figure 9: https://earthistheaim2.wordpress.com/page/7/

Figure 10(a): http://www.vladgym2.ru/index.php/111/60-2010-11-25-02-06-22/696-2013-05-30-02-19-16

Figure 10(b): http://www.vladgym2.ru/index.php/111/60-2010-11-25-02-06-22/696-2013-05-30-02-19-16

Figure 11(a)-(b): http://users.on.net/ mkfenn/page6.htm

Figure 12(c): http://www.diletant.ru/articles/71546/?sphrase_id=711791

Figure 13: http://www.zhv.ru/novosti/priyelbruse-zhdet-otmeny-kto.html

Figure 14(a): http://www.altaj.ru/petroglify-urala?page=0\%2C6

Figure 15:

http://misis.marshruty.ru/Photos/Photo.aspx?PhotoSetItemID=687c687e-2218-455a-81b2-bc48a9bac4a2

\section{Figure 16:}

http://www.uploadimages4free.com/browse_images/archipels_catamaran_bora_bora_lagoon_french_polynesia6701.html

Figure 17: $\underline{\text { http://lebendige-ethik.net/anthropogenesis/French_Polynesia.html }}$

Figure 19: http://www.stena.ee/blog/samyj-bolshoj-budda-v-mire

Figure 20: $\underline{\text { http://forum.awd.ru/viewtopic.php? } \mathrm{f}=758 \& \mathrm{t}=136483}$

Figure 21(a): http://www.travelwithamate.com/best-photography-locations-hawaii/

Figure 2 (b): http://www.bogley.com/forum/showthread.php?66002-Petroglyphs-on-the-Big-Island-of-Hawaii Figure 22:

http://www.art.com/products/p1632368535-sa-i4194619/nico-tondini-mens-meeting-house-at-belau-national-mu seum-koror-republic-of-palau-pacific.htm 
Scientific Research Publishing (SCIRP) is one of the largest Open Access journal publishers. It is currently publishing more than 200 open access, online, peer-reviewed journals covering a wide range of academic disciplines. SCIRP serves the worldwide academic communities and contributes to the progress and application of science with its publication.

Other selected journals from SCIRP are listed as below. Submit your manuscript to us via either submit@scirp.org or Online Submission Portal.
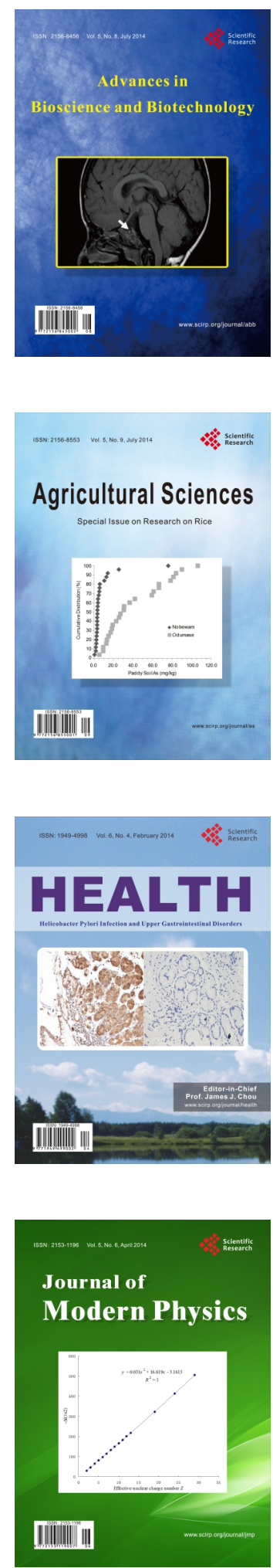
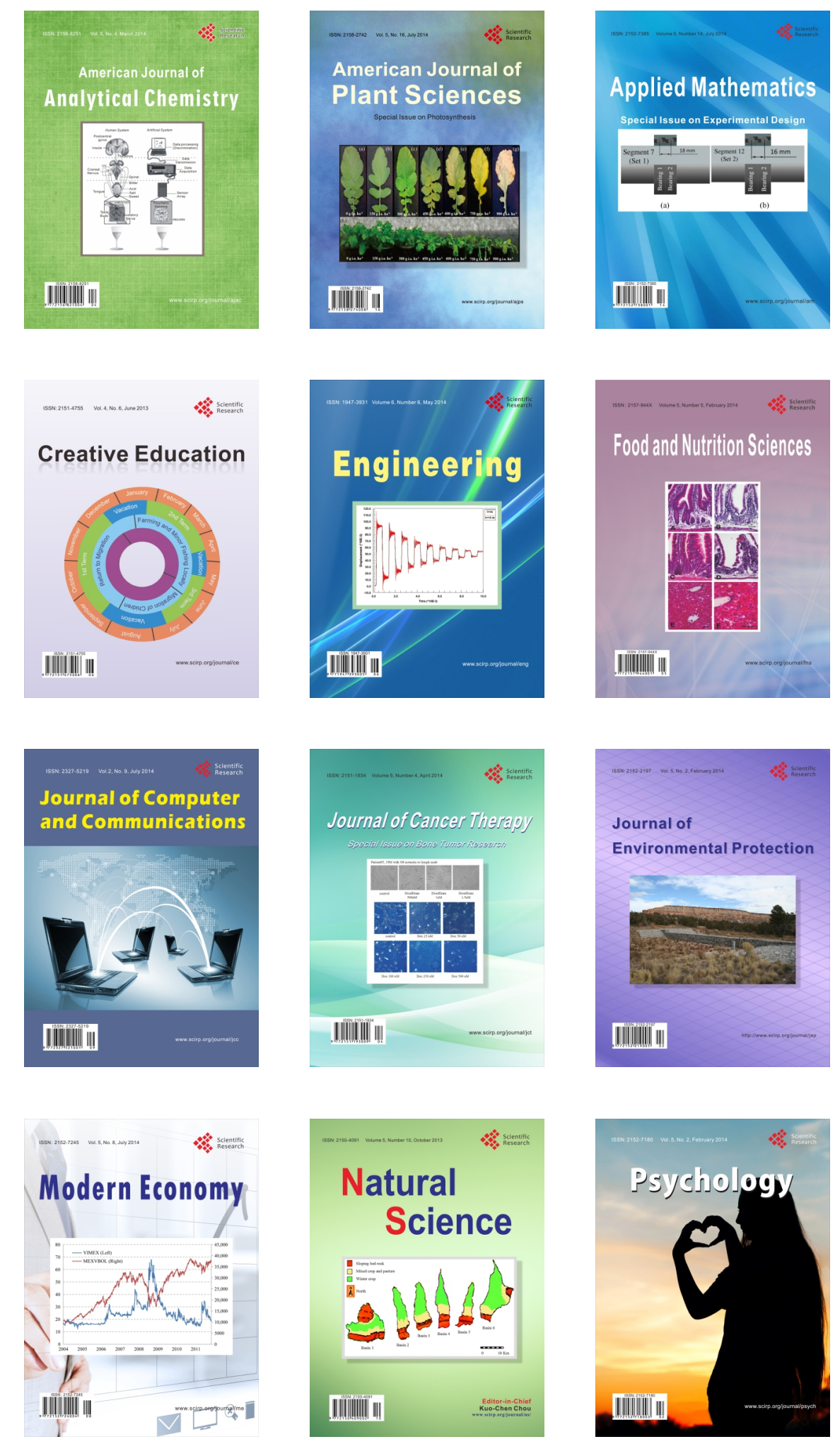